\title{
Production of Green Diesel From Crude Palm Oil (CPO) Through Hydrotreating Process by Using Zeolite Catalyst
}

\author{
Ahmad Zikri ${ }^{1,{ }^{*}}$ Indah Puspita ${ }^{1}$ Erlinawati ${ }^{1}$ Sutini PLAgus $\mathrm{M}^{1}$ Elbi Zalita PB ${ }^{1}$ \\ Andre $\mathrm{K}^{1}$ \\ ${ }^{I}$ Energy Engineering, Chemical Engineering Department, State Polytechnic of Sriwijaya \\ "Corresponding author.Email: ahmad.zikri@polsri.ac.id
}

\begin{abstract}
Green diesel is an alkane compound produced from vegetables oil by hydrogenation which has properties similar to diesel fuel. The ingredients that can be converted into green diesel is Crude Palm Oil (CPO). Green diesel is produced using a catalytic hydrogenation process with 10-30 psia hydrogen injection, the use of natural zeolite catalysts with the variation of catalyst by $1 \mathrm{wt} \%, 2 \mathrm{wt} \%, 3 \mathrm{wt} \%$ and $4 \mathrm{wt} \%$, and temperatures of $350^{\circ} \mathrm{C}, 375^{\circ} \mathrm{C}$, and $400^{\circ} \mathrm{C}$ for $3 \mathrm{~h}$. The purpose of this research is to obtain optimum conditions in the process of hydrotreating CPO into green diesel. The use of $3 \mathrm{wt} \%$ of zeolite catalyst at $400^{\circ} \mathrm{C}$ and $\mathrm{H} 2$ pressure 30 psia was the optimum condition in this study and resulted in a yield percentage of $37.30 \%$. The physical properties of green diesel obtained from this study include density $(782.41-807.99 \mathrm{~kg} / \mathrm{m} 3)$, kinematic viscosity $(2.24-2.53 \mathrm{cSt})$, and flash point $\left(55.1-58.5^{\circ} \mathrm{C}\right)$. The green diesel specifications obtained have fulfill Green Diesel European Standard (The National Standards Authority of Ireland, NSAI).
\end{abstract}

Keywords: green diesel, crude palm oil, zeolite catalyst

\section{INTRODUCTION}

Decreasing fossil fuel resources, along with the increased petroleum demand by emerging economies, drives our society to search for new sources of liquid fuels and focus to improved utilization of renewable energy resources [1]. Considerable work has been done focusing on bio-based fuels production from rapeseed oil, soybean oil, palm oil, karanja oil, waste cooking oil $[2,3]$.

Utilization of New and Renewable Energy in Indonesia has only reached $6 \%$ of the total potential existing energy [4]. Palm oil is a source of raw materials for New and Renewable Energy which is considered the most potential and has a number of advantages as a substitute for the role of fossil energy in the future. Indonesian Palm Oil Association [5] stated that CPO production in 2019 was reached 51.8 million tons. In the research of Putra, et al [6], palm oil was chosen as the raw material for the research, because this oil has an abundant production in Indonesia compared to other vegetable oils.
Fuels from renewable energy source are very attractive alternative to replacing fossil fuels, one of them is Green Diesel. Hydrodeoxygenation vegetable oil or animal fats through catalytic processing with hydrogen is one of the method to produced green diesel and contain mixture of straight-chain C15 to C18 [7]. Hydrodeoxygenation of vegetable oil is one of the key most promising processes for possible production of renewable cleaner automotive fuel (oxygen, sulfur, and aromatics free) [8]. The hydrocarbons product distribution depends on reaction pathways i.e. hydrodeoxygenation (HDO), decarboxylation (DCO2) and decarbonylation (DCO), which also depends on the catalyst properties [9]. Indonesia has large potential reserves of zeolites because it lies within the ring of fire. At present, the zeolitic minerals in Indonesia, which have a potential deposit more than 400 million tons, have been explored. Clinoptilolite is the most abundant zeolite mainly found in a volcanogenic sedimentary rock [10]

So far, the use of zeolite as a heterogeneous catalyst or as support material for generating hydrocarbon-based 
biofuel has rarely been explored. Susanto, et al. [11] reported the synthesis of renewable diesel from oleic acid as a model compound of triglyceride using a $\mathrm{Pd} /$ zeolite-Lampung catalyst at a temperature of $375-$ $400{ }^{\circ} \mathrm{C}$ and pressure of 15 bar H2. Putra, et al (2017) [6] also used HDO in their research where the steps contained in HDO include decarboxylation, decarbonylation, and hydrogenation using $1 \%$ zeolite catalyst. From this literature, it is necessary to continue to carry out sustainable research in the development of vegetable oil into a renewable energy source, namely Green Diesel. In this research using raw materials in the form of CPO and zeolite catalysts.

\section{EXPERIMENTAL}

\subsection{Materials}

The materials that used in this research are CPO, hydrogen gas, zeolite, and $\mathrm{HCl}$. CPO was produced from PT.PP. London Sumatra Indonesia Tbk in the area of Palembang, South Sumatera.

\subsection{Catalyst Preparation}

The zeolite sample that used in this research was natural zeolite from Indonesia. It was pounded became powder and sieved with a measurement of 100 mesh. After that, it was soaked in the solution of $1 \mathrm{M}$ of $\mathrm{HCl}$ for $24 \mathrm{~h}$ and then heated at the temperature of $500{ }^{\circ} \mathrm{C}$ for 4 hours [12]. The analysis results showed that $\mathrm{HCl}$ could reduce the polluter metal of the zeolite and increase the percentage of the main components of zeolite which were $\mathrm{Si}$ and $\mathrm{Al}$ through ion-exchange with $\mathrm{H}+$ ion. The obtained results were subsequently heated on a furnace to delete the ions as the rest of acid like $\mathrm{CO} 2$ and water molecule absorbed by the zeolite pores so that its surface area increased.

\subsection{Catalysts Characterization}

The materials was characterization by Scanning Electron Microscope coupled with Energy Dispersive Spectometer (SEM-EDS) (TESCAN VEGA3 LMU from Czech Republic). SEM is a powerful technique applied in microimaging of a variety surfaces. This technique can be used in exploring the surface structure to determine particle size and texture on that surface [13] and also can identify the chemical composition of zeolite.

\subsection{Hydrotreating Reaction of Crude Palm Oil (CPO)}

Before the hydrotreating process, the reactor was sealed and purged with $\mathrm{H} 2$ (5 minutes) to remove any oxygen content. There are 2 unit reactors, CPO was placed in reactor 1 , a $5 \mathrm{~L}$ batch hydrotreating reactor.
The CPO was used as feed, and zeolite was used as catalyst, with a various of ratio catalysts $1 \mathrm{wt} \%, 2 \mathrm{wt} \%$, $3 \mathrm{wt} \%$ and $4 \mathrm{wt} \%$. The reactions were performed with various of temperature $350{ }^{\circ} \mathrm{C}, 375^{\circ} \mathrm{C}$ and $400^{\circ} \mathrm{C}$ and various of $\mathrm{H} 2$ pressure 10 psia, 15 psia, 20 psia, 25 psia and 30 psia for $3 \mathrm{~h}$.

In reactor 1 there is saturation and cracking process of triglycerides, then in reactor 2 there is a hydrotreating reaction process, where monoglycerides, diglycerides and free fatty acids are converted into straight alkane chains by substituting hydrogen atoms replacing oxygen atoms that are still in carboxylic acids. The product produced from reactor 2 is a gas phase product. The products were condensed by cooler and then store in a separator tank. while the product that is still in the gas phase will rise and return to the accumulator tank to be reacted back together with the gas from reactor 1 . The liquid products was collected every $3 \mathrm{~h}$ for analysis and analyzed using gas chromatography mass spectoscopy (GC-MS) as an chemical analysis.

\subsection{Product Analysis}

Th composition of Green diesel was determined using the Thermo ScientificTM ISQTM 7000 Single Quadrupole GC-MS system, Orlando, USA. The density of green diesel was determined by ASTM D 1298, for kinematic viscosity by ASTM D 445, and for flash point by ASTM D 93.

\section{RESULT AND DISCUSSION}

\subsection{Characterization of Natural Zeolite based catalyst}
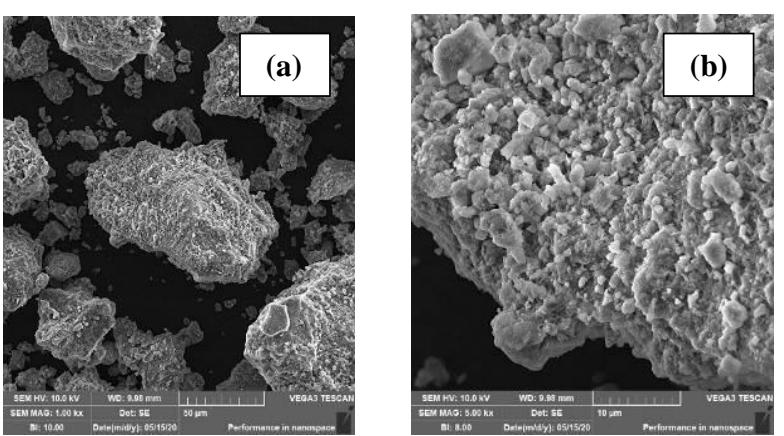


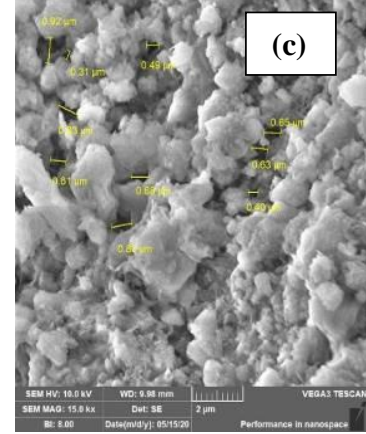

Figure 1. SEM image of natural zeolite (a) x1000(b) x5000 (c) x15000

The solid surface morphology of the zeolite catalyst comprising of the porous crystalline phase indicated by the micrograph of the identification results with Scanning Electron Microscope (SEM) as are presented in Figures 1 and 2. Surface micrographs zeolite shows morphology zeolite surface with brittle character and amorphous. The zeolite has been activated consists of layered lamellars, and between these lamellars there are many cavities of pores of different sizes. Based on the micrograf scale SEM also can determined roughly the particle size diameter and pore size diameter of zeolite based catalyst. The average particle size diameter of zeolite powder is less from $100 \mu \mathrm{m}$. The pore size diameter varies between $0.31 \mu \mathrm{m}$ and $0.92 \mu \mathrm{m}$, which indicates a catalyst material this belongs to the macroporous group.

From the results of the EDS analysis can note that most of the zeolite constituent compounds in the form of oxides. This can be seen from the results content of $\mathrm{O}$ is large enough. And the largest possible oxide are the Silica and Alumina groups, because the $\mathrm{Si}$ and $\mathrm{Al}$ content are the largest, and this corresponds to the compound composition of the zeolite composed of silica compounds - alumina. From the EDS results can also known that the $\mathrm{Al}$ content is $6.21 \%$ and $\mathrm{Si}$ is $28.38 \%$ (Table 1).

Table 1. Chemical compound in natural zeolite catalys analyzed by EDS

\begin{tabular}{ccccc}
\hline Element & $\begin{array}{c}\text { No. } \\
\text { Atom }\end{array}$ & Netto & $\begin{array}{c}\text { Mass. } \\
\text { Norm } \\
(\%)\end{array}$ & $\begin{array}{c}\text { Atom } \\
(\%)\end{array}$ \\
\hline $\mathrm{O}$ & 8 & 27740 & 50.78 & 61.66 \\
$\mathrm{Si}$ & 14 & 109479 & 28.38 & 19.63 \\
$\mathrm{Al}$ & 13 & 16170 & 6.21 & 4.27 \\
$\mathrm{C}$ & 6 & 781 & 5.27 & 8.53 \\
$\mathrm{Na}$ & 11 & 5513 & 4.35 & 3.67 \\
$\mathrm{~K}$ & 19 & 5574 & 1.71 & 0.85 \\
$\mathrm{In}$ & 49 & 2747 & 1.28 & 0.22 \\
$\mathrm{Ca}$ & 20 & 2942 & 0.97 & 0.47
\end{tabular}

\begin{tabular}{ccccc}
\hline Element & $\begin{array}{c}\text { No. } \\
\text { Atom }\end{array}$ & Netto & $\begin{array}{c}\text { Mass. } \\
\text { Norm } \\
(\%)\end{array}$ & $\begin{array}{c}\text { Atom } \\
(\%)\end{array}$ \\
\hline $\mathrm{Fe}$ & 26 & 1539 & 0.79 & 0.27 \\
$\mathrm{Mg}$ & 12 & 544 & 0.28 & 0.05 \\
\hline & Sum & & 100 & 100 \\
\hline
\end{tabular}

\subsection{Optimization Studies}

\subsubsection{Effect of the catayst loading}

The effect of zeolite loading (1-4\%) on the percent yield, density, kinematic viscosity and flash point at $400^{\circ} \mathrm{C}, 3 \mathrm{~h}$ reaction time and hydrogen pressure $30 \mathrm{psia}$ operation were shown in Fig.2(a-d).
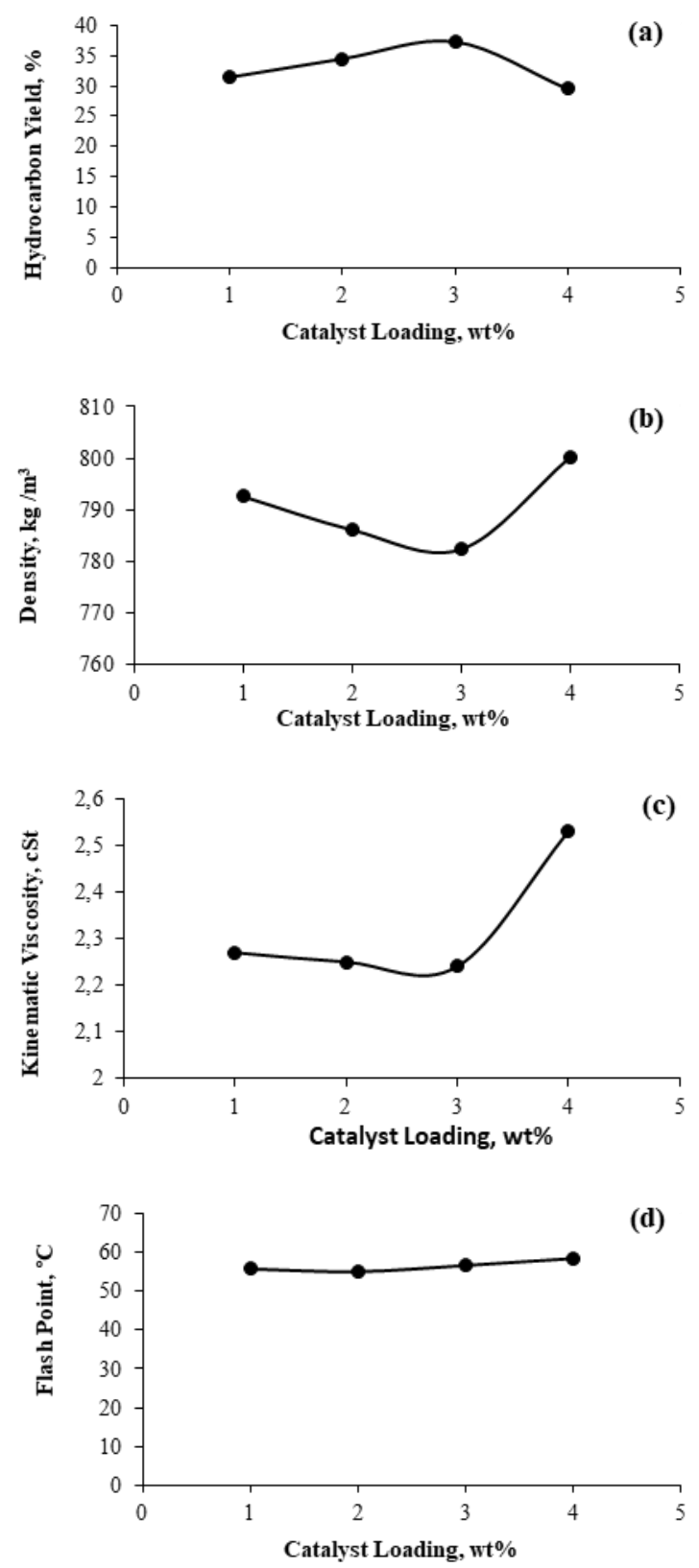
Figure 2. Effect of zeolite loading on the hydrocarbon (a) yield, (b) density, (c) viscosity and (d) flash point of green diesel.

Hydrocarbon yield. Based on the research, optimum hydrocarbon yield $(37.30 \%)$ was obtained with $3 \%$ zeolite catalyst. Increasing catalyst loading within range 1-3 wt $\%$ has led to the increment of catalyst active sites made available for the reaction [15]. Increasing catalyst loading to $4 \%$ has resulted in reduction of hydrocarbon yield, which is caused by parallel or secondary reactions such as polymerization. Yield reduction was known after the maximum yield and the reduction caused by cracking of the deoxygenated liquid product into lighter fractions [16].

Density. The product density obtained was around 782.41-800.23 kg/m3, which qualified Green Diesel European Standard. Based on the research, it was found that the more of catalyst used, the lower density of the resulting product. It can be stated that the density is based on the amount of carbon chains, the shorter number of carbon chains, the smaller density obtained. The excess of catalyst loading make CPO not converted into green diesel products, because the more of catalyst used, the residue or coke will be formed on the active side of the catalyst, if it is not proportional to the temperature increase. Coke formation occurs in all catalytic cracking of used palm oil [17] and will affect to the density (Fig.2-b) and viscosity (Fig.2-c) of the product.

Kinematic Viscosity. Kinematic viscosity (Fig.2-c) increases with chain length. From the graph, it can be seen that the viscosity value obtained decreases when the catalyst loading used is higher. Generally, the aliphatic and aromatic hydrocarbons, which are the major components of petrodiesel, display a smaller viscosity range with lower viscosities due to their lack of oxygen or other heteroatoms [18].

Flash Point. Measurement of the flash point is carried out using a flash point tester. The determination of the flash point is concerned with the safety in fuel storage. From the results of the flash point test obtained between $55.1^{\circ} \mathrm{C}-58.5^{\circ} \mathrm{C}$, which qualified Green Diesel European Standard. The flash point relates to the volatility of the fuel; consequently, it will influence the number of light fractions present in a fuel sample [19]. Good experimental flash point data and estimation methods are vital for evaluating the handling of flammable liquids for safety regulations [20]. Flash point has safety implications and is therefore used to as certain associated explosion hazards and fire of a flammable solution [21]

\subsubsection{Effect of the temperature}

The effect of the reaction temperature from $350^{\circ} \mathrm{C}, 375^{\circ} \mathrm{C}$, and $400^{\circ} \mathrm{C}$ on the percent yield, density, kinematic viscosity, and flashpoint were shown in Fig. 3(a-d).
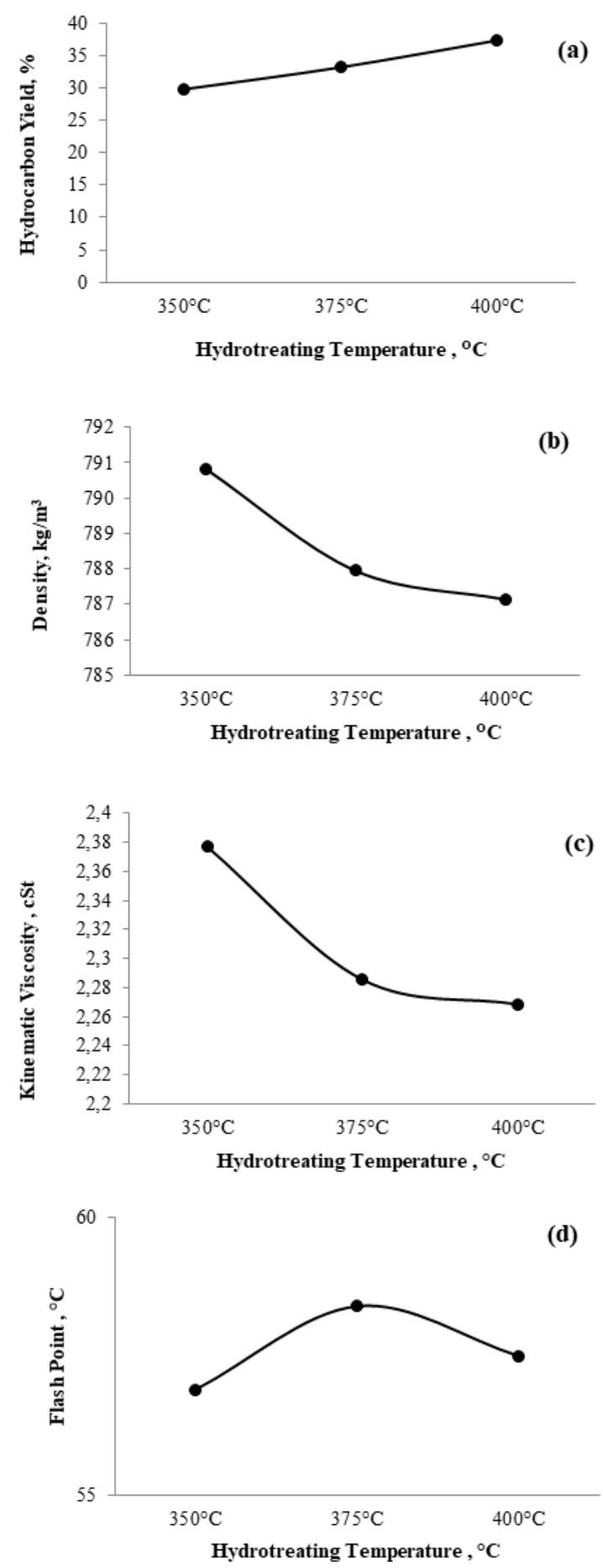

Figure 3. Effect of hydrotreating temperature on the hydrocarbon (a) yield, (b) density, (c) viscosity and (d) flash point of green diesel.

Hydrocarbon yield. From the graph, it can be seen that as the reaction temperature increase from $350^{\circ} \mathrm{C}$ to $375^{\circ} \mathrm{C}$, a progressive proportion of yield also increase. This is because when the temperature is increased then the cracking process will occur more easily and optimally [22]. The highest yield of CPO was achieved 
at $400^{\circ} \mathrm{C}$ with a total yield of $37.30 \%$. From the result, $400^{\circ} \mathrm{C}$ was selected as the optimum hydrotreating temperature after considering the yield factor.

Density. Based on the research, it was found that the more high temperature used, the lower density of the resulting product. High temperature will enhance the occurrence of secondary reaction which turn into light product [23]. It can be stated that the density is based on the number of carbon chains, the shorter number of carbon chains, the smaller density obtained. The product density obtained was around 787.14-790.83 kg/m3, which qualified the green diesel European standard.

Kinematic Viscosity. The kinematic viscosity increases with chain length, the shorter the chain then the more the value. From the graph, it can be seen that the viscosity value obtained decreases when the heating temperature used is higher. The smaller the viscosity, the lighter the fraction contained in the product [24]. The kinematic viscosity of product obtained was around 2.26-2.37 cSt, which qualified the Green Diesel European Standard.

Flash Point. From the results of the flash point test obtained between $56.9^{\circ} \mathrm{C}-58.4^{\circ} \mathrm{C}$, which qualified green diesel European standard. In the graph it can also be seen that the flash point at $350^{\circ} \mathrm{C}$ is lower than the flash point at $375^{\circ} \mathrm{C}$. This happens because of the volatile matter content in the product can cause the resulting flash point to be lower. At a temperature of $400^{\circ} \mathrm{C}$ the resulting flash point is lower than the flash point at $375^{\circ} \mathrm{C}$, this happens because the flash point affects the viscosity of the product produced. The higher the viscosity, the higher the flash point of a compound [25]. Flashpoint is parameters of practical importance, the higher is the safety during handling, transportation, and storage [26].

\subsubsection{Effect of the $\mathrm{H}_{2}$ pressure}

The research was conducted with fixed variables in the form of natural zeolite catalyst $3 \mathrm{wt} \%$, temperature $400^{\circ} \mathrm{C}$, the amount of raw material 2 liters, and operating time for 3 hours. Variable in the form of hydrogen pressure 10 psia, 15 psia, 20 psia, 25 psia, 30 psia.

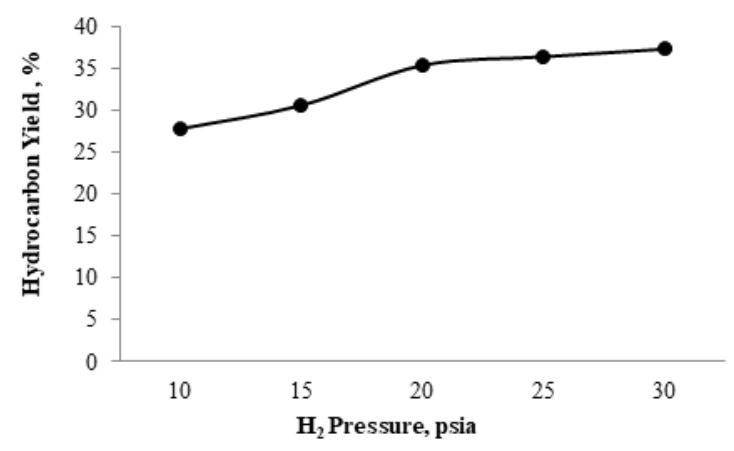

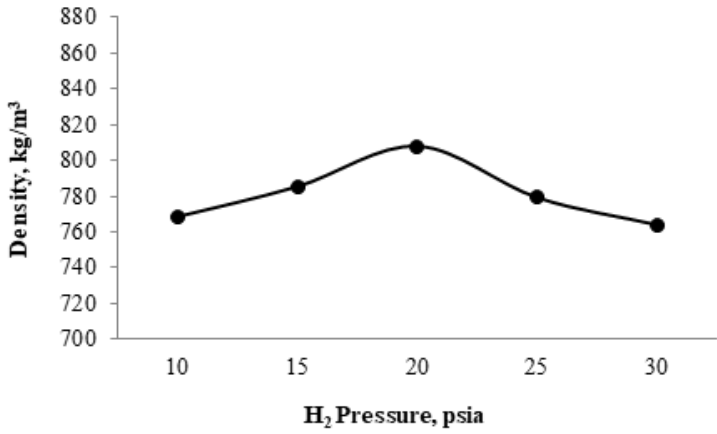
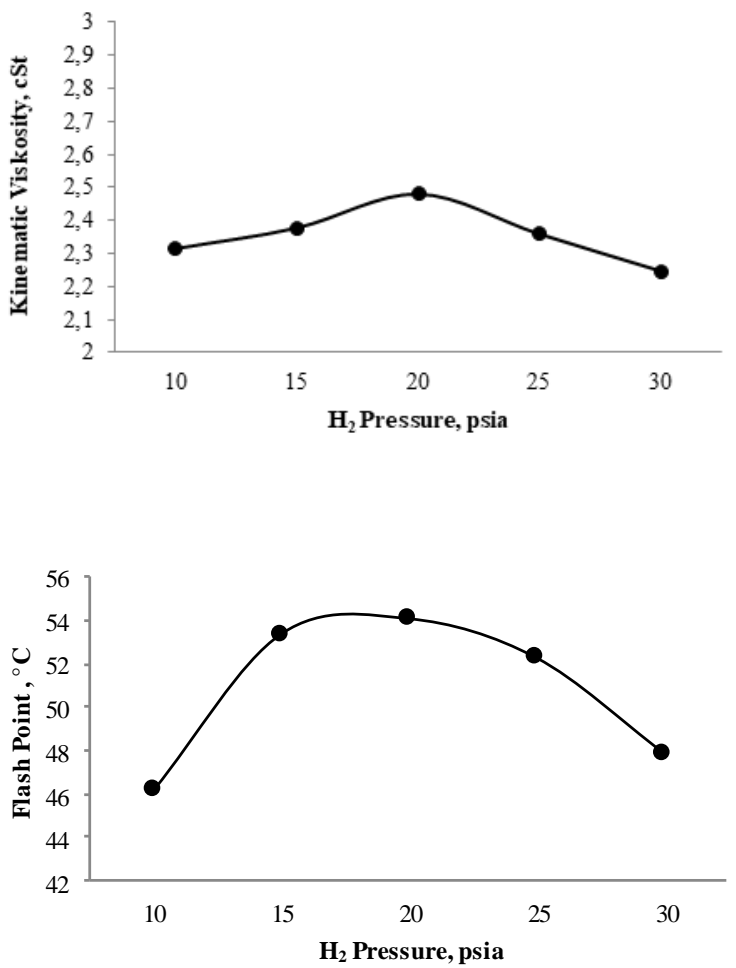

Figure 4. Effect of pressure of hydrogen inject on the hydrocarbon (a) yield, (b) density, (c) viscosity and (d) flash point of green diesel.

Hydrocarbon yield. After obtaining the data, then analyzed the lowest yield was obtained at the initial hydrogen pressure of 10 psia with a value of $27.78 \%$, while for the highest percent yield was at 30 psi with a\% yield of $37.30 \%$. This proves that the difference in initial low and high initial hydrogen pressure has affects the formation process. The initial low hydrogen pressure is more influential on the decarboxylation and decarbonylation processes to produce $\mathrm{nC} 17 \mathrm{H} 36$ and $\mathrm{nC} 15 \mathrm{H} 32$ ), while for high hydrogen pressure more affects the hydrodeoxygenation reaction process to produce $(\mathrm{nC} 18 \mathrm{H} 38$ and $\mathrm{nC} 16 \mathrm{H} 34)$ but in this process, the resulting product requires a water treatment process because the product produced contains more water [27].

Density. From the research, obtained a product with a density range of $768.52 \mathrm{~kg} / \mathrm{m} 3-807.99 \mathrm{~kg} / \mathrm{m} 3$, indicating the product has its own characteristics. In the research, the density is influenced by the initial 
hydrogen pressure, the injected hydrogen affects the carbon chains formed. In excess $\mathrm{H} 2$ conditions, the process that occurs is a hydrodeoxygenation process and in low $\mathrm{H} 2$ conditions the processes that occur are decarboxylation and decarbonylation [28]. The density itself is influenced by the carbon chain of the compound that is formed, the higher the density, the longer the number of carbon atoms formed, and vice versa. most of these compounds are members of the paraffin, naphthenic, or aromatic class of hydrocarbons; each class has different chemical and physical properties [29]. Insufficient $\mathrm{H} 2$ leads to the formation of coke on the surface of the catalyst and deactivation of the catalyst. As a result, green diesel yields decreased and the profile of green diesel species changed [30].

Kinematic Viscosity. The kinematic viscosity is shown in the figure. Viscosity is the time it takes for a certain volume of sample to flow through the capillaries under gravity. For a given carbon number, naphthene compounds have a slightly higher viscosity than paraffins or aromatics [29]. In processes using H2 pressure and reaction temperatures tend to be lower to promote the coke formation reaction rather than the hydrogenation reaction. [31]. Studied its effect of reaction temperature on coke formation, finding that increased temperature led to severe coke formation despite increased HDO levels.

Flash Point. In the flash point test, green diesel products were found with a range of 46.2-54.1 oC. For values that do not meet European standards due to the presence of volatile compounds, this is due to the lack of temperature in the condenser to condense the product which is still in the form of vapor produced during the process. product is quicker to start up. a flash point that is too low is also undesirable because it will cause detonation, ie small explosions that occur before the fuel enters the combustion chamber. This can cause damage to tools such as pistons, cylinder walls [29]. Indicating that a low $\mathrm{H} 2 / \mathrm{BG}$ ratio gives the best green diesel selectivity (combined selectivity of saturated and unsaturated C13-C18 hydrocarbons) [32].

\subsection{GC-MS analysis}

The green diesel by crude palm oil with 3 wt $\%$ zeolite catalyst and $\mathrm{H}_{2} 30$ psia at $400^{\circ} \mathrm{C}$ was tested by using Thermo Scientific ${ }^{\mathrm{TM}}$ ISQ $^{\mathrm{TM}} 7000$ Single Quadrupole GC-MS system. Chemical composition was determined an analyzer GC-MS (Fig.4), the resulting product was dominated by the chain of $\mathrm{C}_{15}-\mathrm{C}_{18} 59.47 \%$. While other compositions are gasoline, kerosene and naphta $(17.15 \%)$, lubricating oil $(0.98 \%)$, paraffin $(0.55 \%)$ and other compounds $(21.87 \%)$.

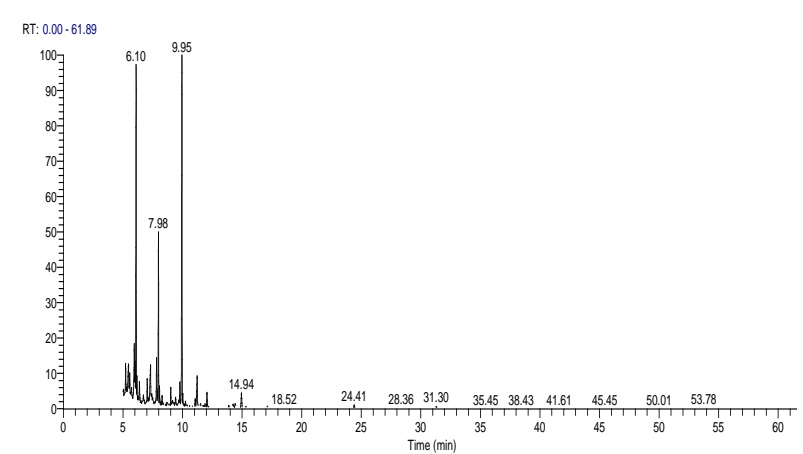

Figure 5. GC-MS analysis of green diesel product

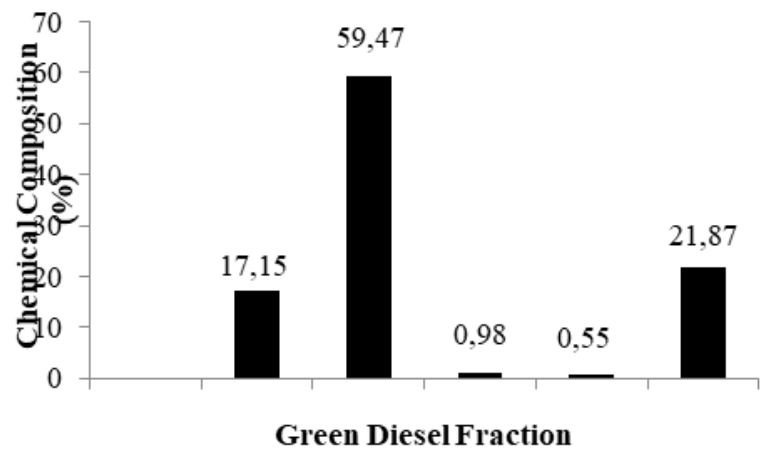

Figure 6. Green Diesel Fraction

The compounds of $\mathrm{C} 5-\mathrm{C} 14$ chain contained in the product due to the continuous thermal cracking reaction and convert the compound into a lighter fraction. It also formed a myristic acid which has a chemical

by using $\mathrm{CPO}$, zeolite catalyst, and $\mathrm{H} 212$ bar at $375^{\circ} \mathrm{C}$, through GC-MS analysis product obtained was dominated by the chain $\mathrm{C} 15-\mathrm{C} 1855.93 \%$ that was range of diesel fuel. Susanto, et al (2014) [11] in their research that produce renewable diesel through hydrodeoxygenation by using $\mathrm{Pd} /$ Zeolite catalysts at $375-400^{\circ} \mathrm{C}$ and 15 bar $\mathrm{H} 2$ pressure through GC-MS analysis product obtained by the chain $\mathrm{C} 15-\mathrm{C} 18$ $53.33 \%$. It means that the result from this research are not too different from the previous reseach.

\section{CONCLUSION}

The optimum hydrotreating process of crude palm oil using natural zeolite catalyst to produce green diesel is in $3 \mathrm{wt} \%, 400^{\circ} \mathrm{C}$, and $30 \mathrm{psia}$ of $\mathrm{H} 2$ inject with a product yield of $37.3 \%$ which cointained the chain $\mathrm{C} 15$ C18 55.93\% that was range of diesel fuel. Based on this research, the products contain density 782.41-807.99 $\mathrm{kg} / \mathrm{m} 3$, kinematic viscosity 2.24-2.53 cSt, and flash point $55.1-58.5^{\circ} \mathrm{C}$, which qualified the specification of Green Diesel European Standard. 


\section{ACKNOWLEDGMENTS}

The authors would like to acknowledge the financial support from the directorate of research and community service, ministry of research, technology and higher education for providing funding Penelitian Nasional No 030/SP2H/LT/DRPM/2020.

\section{REFERENCES}

[1] De S, Saha B, and Luque R 2015 Hydrodeoxygenation Processes: Advances on Catalytic Transformations of Biomass-Derived Platform Chemicals into Hydrocarbon Fuels Bioresource Technology 178 (2015):108-118

[2] Herskowitz M, Landau M V, Reizner Y, and Berger D A commercially-viable one-step process for production of green diesel from soybean oil on Pt/SAPO-11. Fuel 2013;111:157-64

[3] Kim S K, Brand S, Lee H, Kim Y, and Kim J 2013 Production of renewable diesel by hydrotreatment of soybean oil: effect of reaction parameters Chem Eng $J$ 228114-23

[4] Ministry of Energy and Mineral Resources RI 2020 Strengthening Economic Resilience Targeted NRE Portion 13,4 Percent in 2020

[5] Indonesian Palm Oil Association 2019 The performance of the Indonesian palm oil industry in 2019 https://gapki.id/KINERJA_INDUSTRI_SAWIT_ INDONESIA_2019.pdf

[6] Putra R, Lestari W W, Wibowo F R, and Susanto B H 2018 Fe/Indonesian Natural Zeolite as Hydrodeoxygenation Catalyst in Green Diesel Production from Palm Oil 13(2) 245-255

[7] Douvartzides S L, Charisiou N D, and Papageridis K N 2019 Green Diesel: Biomass Feedstocks Production Technologies Catalytic Research Fuel Properties and Performance in Compression Ignition Internal Combustion Engines (12) 809

[8] Mariam A, Azizan M T, Ramli A, Yusup S, and $\begin{array}{lllll}\text { Alnarabiji } & \text { M } & \text { S } & 2018 \quad \text { Catalytic }\end{array}$ hydrodeoxygenation of rubber seed oil over sonochemically synthesized ni-mo/ $\gamma-\mathrm{al}_{2} \mathrm{O}_{3}$ catalyst for green diesel production. Ultrasonics Sonochemistry.

[9] Zarchin R, Rabaev M, Nehemya R V, Landau M V, and Herskowitz M 2015 Hydroprocessing of soybean oil on nickel-phosphide supported catalysts Fuel 139 684-691

[10] Wang S and Peng Y 2010 Natural zeolites as effective adsorbents in water and wastewater treatment Chem Eng J 156 (1) 11-24

[11] Susanto B H, Nasikin M, and Wiyo A 2014 Synthesis of Renewable Diesel through hydrodeoxygenation Using Pd/Zeolite Catalysts Procedia Chem 9: 139-150

[12] Sumari, Sholihah N, Aisiyah M M, Oktaviani I, Khilmi N, and Prakasa Y F 2018 Effectiveness of Modified Natural Zeolite through Acid Activation as A Catalyst on Cellulose Conversioninto Glucose from Cotton Assisted by Ultrasonic Universitas Negeri Malang: Malang.

[13] Mansouri N, Rikhtegar N, Panahi H A, Atabi F, and Shahraki B K 2013 Porosity Characterization and Structural Properties of Natural Zeolite Clinoptilolite as a Sorbent Vol $39(1)$

[14] The National Standards Authority of Ireland (NSAI) 2018 Automotive fuels - Paraffinic diesel fuel from synthesis or hydrotreatment Requirements and test methods (Green Diesel European Standars EN15940:2016/A1:2018).

[15] Kwon K C, Mayfield H, Marolla T, Nichols B, and Mashburn M 2011 Catalytic deoxygenation of liquid biomass for hydrocarbon fuels Renew Energy 36 907-915

[16] Alsultan-Abdulkareem G, Mijan A, Mansir N, Lee $\mathrm{H} \mathrm{V}$, Zainal Z, Islam A, and Taufiq-Yap Y H 2018 Pyro-lytyc De-oxygenation of Waste Cooking Oil for Green Diesel Production Over $\mathrm{Ag}_{2} \mathrm{O}_{3} \mathrm{La}_{2} \mathrm{O}_{3} / \mathrm{AC}$ Nano-Catalyst Journal of Analytical and Applied Pyrolisis

[16] Mortensen P M, Grunwaldt J, Jensen P A, Knudsen K G, and Jensen A D 2011 Applied Catalysis: general A review of catalytic upgrading of biooil to engine fuels Appl Catal A Gen 407 1-19

[17] Chang W and Hand T C T, 2013 Catalytic Cracking of Used Palm Oil Using Composite Zeolite The Malaysian Journal of Analytical Sciences 17(1)176-84

[18] Knothe G, and Steidley K R 2005 Kinematic viscosity of biodiesel fuel components and related compounds. Influence of compound structure and comparison to petrodiesel fuel components Fuel 84(9) 1059-1065 
[19] Bahadur N P, Boocock D G B, and Konar S K 1995 Liquid Hydrocarbons from Catalytic Pyrolysis of Sewage Sludge Lipid and Canola Oil: Evaluation of Fuel Properties Energy \& Fuels 9(2)

[20] Khalili T, Moghaddam Z A 2011 Measurement and Calculation of Flash Point of Binary Aqueous-Organic and Organic-Organic Solutions Fluid Phase Equilib 312 101-105

[21] Phoon L Y, Mustaffa A A, Hashim H, and Mat R, 2014 A Review of Flash Point Prediction Models for Flammable Liquid Mixtures. Industrial \& Engineering Chemistry Research 53(32)

[22] Heriyanto H, Sd S M, Heriyanti S I, Sholehah I, and Rahmawati A 2018 Synthesis of Green Diesel From Waste Cooking Oil Through Hydrodeoxygenation Technology With NiMo / Y -Al 2 O 3 Catalysts 1-6

[23] Arend M, Nonnen T, Hoelderich W F, Fischer J, and Groos J 2011Catalytic deoxygenation of oleic acid in continuous gas flow for oxygen reduction reaction in PEMFCs $J$ Mater Chem 22, 20977

[24] Aziz I 2019 Upgrading Crude Biodiesel of Using Cooking Oil Using H-Zeolite Catalyst Jurnal Kimia Valensi Vol 5(1) 79-86

[25] Zaher F, and Gad M S 2017 Catalytic Cracking of Vegetable Oil for Producing Biofuel Egypt $J$ Chem Vol 60. No 2, 291-300

[26] Candeia R A, Silva M C D, Carvalho Filho J R, Brasilino M G A, Bicudo T C, Santos I M G, and Souza A G 2009 Influence of soybean biodiesel content on basic properties of biodiesel-diesel blends Fuel 88(4), 738-743

[27] Liu Y, Sotelo-Boyás R, Murata K, Minowa T and Sakanishi K 2012 Production of BioHydrogenated Diesel by Hydrotreatment of High-Acid-Value Waste Cooking Oil over Ruthenium Catalyst Supported on AlPolyoxocation-Pillared Montmorillonite National Institute of Advanced Industrial Science and Technology

[28] Kethane T C 2016 Hydro-processing of cottonseed oil for renewable fuel production: Effect of catalyst type and reactor operating parameters Potchefstroom Campus of the North-West University

[29] Bacha J, John, Freel J, Gibbs A 2007 Diesel fuel Technical Review Book of Cevron Coorporation 30-36

[30] McCall M J, Marker T L, Marinangeli R E, and KocalJoseph A 2009 In United States Patent Application Publication US Vol 0162264

[31] Li Ya, Zhang C, Hou X, Zhang R, and Tang X 2015 Deposition of coke on Ni / HZSM-5 in bio-oil hydrodeoxygenation processing

[32] Elvansari 2013 Green diesel production via catalytic hydrogenation/decarboxylation of triglycerides and fatty acids of vegetable oil and brown grease Graduate School of Wayne State University Detroit Michigan 